\title{
Article \\ Consistency Is Key When Setting a New World Record for Running 10 Marathons in 10 Days
}

\author{
Nicolas Berger ${ }^{1, *(\mathbb{D}}$, Daniel Cooley ${ }^{1}$, Michael Graham ${ }^{1}\left(\mathbb{D}\right.$, Claire Harrison $^{2}$, Georgia Campbell ${ }^{1}$ and Russ Best $^{3}(\mathbb{D}$ \\ 1 School of Health and Life Sciences, Teesside University, Borough Road, Middlesbrough TS1 3BA, UK; \\ D.Cooley@tees.ac.uk (D.C.); Michael.Graham@tees.ac.uk (M.G.); G.Campbell@tees.ac.uk (G.C.) \\ 2 Newcastle Nutrition Community Team, The Newcastle upon Tyne Hospitals NHS Foundation Trust, \\ Newcastle NE7 7AH, UK; claire@c-harrison.co.uk \\ 3 Centre for Sports Science \& Human Performance, WINTEC, Hamilton 3240, New Zealand; \\ Russell.Best@wintec.ac.nz \\ * Correspondence: n.berger@tees.ac.uk; Tel.: +44-1642384267
}

check for updates

Citation: Berger, N.; Cooley, D.; Graham, M.; Harrison, C.; Campbell, G.; Best, R. Consistency Is Key When Setting a New World Record for Running 10 Marathons in 10 Days. Int. J. Environ. Res. Public Health 2021, 18, 12066. https://doi.org/10.3390/ ijerph182212066

Academic Editors: Britton W. Brewer and Paul B. Tchounwou

Received: 30 September 2021

Accepted: 16 November 2021

Published: 17 November 2021

Publisher's Note: MDPI stays neutral with regard to jurisdictional claims in published maps and institutional affiliations.

Copyright: (c) 2021 by the authors. Licensee MDPI, Basel, Switzerland. This article is an open access article distributed under the terms and conditions of the Creative Commons Attribution (CC BY) license (https:// creativecommons.org/licenses/by/ $4.0 /)$.
Abstract: Background: We describe the requirements and physiological changes when running 10 consecutive marathons in 10 days at the same consistent pace by a female ultra-endurance athlete. Methods: Sharon Gayter (SG) 54 yrs, $162.5 \mathrm{~cm}, 49.3 \mathrm{~kg}$ maximal oxygen uptake $\left(\mathrm{VO}_{2}\right.$ max) $53 \mathrm{~mL} / \mathrm{kg}^{-1} / \mathrm{min}^{-1}$. SG completed $42.195 \mathrm{~km}$ on a treadmill every day for 10 days. We measured heart rate (HR), Rating of Perceived Exertion (RPE), oxygen uptake $\left(\mathrm{VO}_{2}\right)$, weight, body composition, blood parameters, nutrition, and hydration. Results: SG broke the previous record by $\sim 2.5 \mathrm{~h}$, with a cumulative completion time of $43 \mathrm{~h} 51 \mathrm{~min} 39 \mathrm{~s}$. Over the 10 days, weight decreased from $51 \mathrm{~kg}$ to $48.4 \mathrm{~kg}$, bodyfat mass from $9.1 \mathrm{~kg}$ to $7.2 \mathrm{~kg}$ (17.9\% to $14.8 \%)$, and muscle mass from $23.2 \mathrm{~kg}$ to $22.8 \mathrm{~kg}$. For all marathons combined, exercise intensity was $\sim 60 \% \mathrm{VO}_{2} \max ; \mathrm{VO}_{2}$ $1.6 \pm 0.1 \mathrm{~L} \cdot \mathrm{min}^{-1} / 32.3 \pm 1.1 \mathrm{~mL} \cdot \mathrm{kg}^{-1} \cdot \mathrm{min}^{-1}$, RER $0.8 \pm 0$, HR $143 \pm 4$ b.min ${ }^{-1}$. Energy expenditure (EE) was $2030 \pm 82 \mathrm{kcal} /$ marathon, total EE for 10 days (including BMR) was 33,056 kcal, daily energy intake (EI) $2036 \pm 418 \mathrm{kcal}(20,356 \mathrm{kcal}$ total), resulting an energy deficit (ED) of 12,700 kcal. Discussion: Performance and pacing were highly consistent across all 10 marathons without any substantial physiological decrements. Although overall EI did not match EE, leading to a significant $\mathrm{ED}$, resulting in a $2.6 \mathrm{~kg}$ weight loss and decreases in bodyfat and skeletal muscle mass, this did not affect performance.

Keywords: ultra-endurance; Marathon; pacing; energy expenditure; world record; running

\section{Introduction}

Historically the most famous ultra-endurance feat was that of the dispatch runner Pheidippides, who ran from Marathon to Athens to deliver the message of the victory of the battle of Marathon in 530 BC. He died immediately after delivering the message of "Joy to you, we've won!", which seems surprising as the distance from Athens to Marathon is 'just' $40 \mathrm{~km}$. However, Pheidippides had previously already covered $480 \mathrm{~km}$ in two days when running to and from Sparta to request help when the Persians landed at Marathon [1]. Thus, although the rather more modest distance of $40 \mathrm{~km}$ underplays his stamina, the fact that Pheidippides died whilst carrying out his duties has defined this now-famous distance.

Pheidippides was a hemerodromos, who were day-long runners in the Greek military who covered large distances on foot, often over difficult mountainous terrain. It has been reported that they often did not sleep for days to be able to carry out their duty and deliver messages [2]. Their nutrition was one high in carbohydrates, protein, fat and salt, which they consumed via figs and other fruit, olives, dried meats and a very early version of the energy gel called pasteli. This was a paste made from ground sesame seeds and honey. The day-long runners also ate small amounts of sea buckthorn, which they believed enhanced endurance and stamina [1]. 
Today, ultra-running (UR) is no longer required to deliver messages, but people typically take part because of the extremely challenging nature. UR is considered any running event in excess of a marathon $(>42.2 \mathrm{~km}$; IAAF, 1997). Races are contested over standardised race distances $(50 \mathrm{~km}, 50$ miles, $100 \mathrm{~km}$ and 100 miles (IAU, 2007)), or time periods (e.g., $24 \mathrm{~h}$ ) in either single-day, or multi-day events. UR events may take place on a variety of terrains, ranging from treadmills to remote wilderness, and has increased in popularity and increasingly, more research about the impact of these events on the human body is being carried out [3]. However, there is still only limited literature, which includes data from successful world record attempts, or that includes all necessary data to calculate energy expenditure (EE), such as $\mathrm{VO}_{2}$, or pre and post-haematological and body composition data. Typically, they include only one of the aforementioned measures or estimates, e.g., of energy expenditure [4,5]. Therefore, we set out to collect detailed data on a female multiple world record-holding ultra-runner during her successful attempt at breaking the world record for running 10 marathons in 10 days on a treadmill.

It is still not fully clear what effects repeated ultra-endurance performances have on the body, especially in relation to changes in body mass and corresponding body composition, in particular, muscle mass and fat-free mass [3]. Matching EE during UR is often problematic due to logistical constraints and the extremely common gastro-intestinal complaints suffered by competitors [6-8]. Physiological problems arising after UR nearly always include decreases in body mass and dehydration, loss of skeletal muscle mass and increases in total body water $[9,10]$. This trend is also apparent in the back-to-back triathlon format of Ultraman, which consists of completing multiple long-distance triathlons over consecutive days [11,12] UR has also been shown to result in haemolysis [13] and haematocrit can decrease $[14,15]$, although a reduction in haemoglobin is typically the result of plasma volume expansion [15].

Pacing and consistent effort in UR are key to performance and it has been shown that the most successful UR athletes set and follow a pre-determined pacing strategy, and inexperienced and/or younger runners tend to start faster and fade as the event progresses [16]. Being able to perform repeatedly and consistently over several days requires careful planning and well-organized recovery strategies. With inadequate recovery, there will be significant decrements in bodily systems, which could affect performance [17]. Recovery strategies include carbohydrate and protein intake to replenish depleted glycogen stores and enhance repair from muscle damage, as well as manual therapies, such as massage or ice baths $[18,19]$.

The aim of the present study was to investigate the effects of running 10 marathons (total $421.95 \mathrm{~km}$ ) on 10 consecutive days on changes in body composition and haematology, to examine the pacing strategy, calculate the energy intake and expenditure, and analyse recovery methods. There were follow-up measurements 1-day and 1-week post-completion of the final marathon. We expected decreases in body fat and muscle mass, as well as a significant energy deficit, but no haematological changes.

\section{Materials and Methods}

Participant: Sharon Gayter (SG) is a 57-year-old ultra-endurance runner (54 yrs at the time of the event) with over 30 years' competitive experience. She has competed internationally for GB at $100 \mathrm{~km}$ and $24 \mathrm{~h}$, completed more than 50,000 km of racing, finished more than 1700 races, and finished more than 400 marathons and over 160 ultraendurance events.

\subsection{Record Attempt}

SG successfully completed a world record attempt in accordance with Guinness World Record requirements. To be eligible for a record, efforts must be based upon one variable, breakable, measurable, standardisable, and verifiable (Guinness World Records Ltd., 2019) with supporting evidence submitted as per Guinness World Records requirements (Guin- 
ness World Records Ltd., 2019). The record involved the completion of, and cumulative time for 10 marathons in 10 days completed on a treadmill in the UK at Teesside University.

SG started running every day at 11 am on a treadmill located in the foyer of Teesside University and did not stop running until she completed the full distance of $42.195 \mathrm{~km}$. Temperature was kept at a constant $20^{\circ} \mathrm{C}$ throughout the attempt. We recorded weight $(\mathrm{kg})$, body composition, sleep data, lung function, blood lactate $\left(\mathrm{mmol} . \mathrm{L}^{-1}\right)$, blood glucose $\left(\mathrm{mmol} . \mathrm{L}^{-1}\right)$, cholesterol, haemoglobin (g.dl) and haematocrit (\%) before and after each marathon, 1-day and 1-week post-attempt.

\subsection{Measures}

\subsubsection{Body Composition}

Body mass (Seca 869, Birmingham, UK) and body composition were assessed via a portable bioelectrical impedance analysis (BIA) machine (InBody S10, 13,850 Cerritos Corp Dr, Unit C, Cerritos, CA, USA) to determine body mass (BM), skeletal muscle mass $(\mathrm{SM})$, percent body fat $(\% \mathrm{BF})$ and total percent body water $(\% \mathrm{TBW})$. Measurements were taken before the start of the attempt, at the same time of day (10.30 a.m.) before and immediately after each marathon, as well as 1-day and 1-week post-attempt completion. BIA measurements were performed with the athlete standing in an upright position, barefoot, with legs and thighs not touching, and the arms not touching the torso. A total of 6 electrodes in total were attached to: the thumb and middle finger of both hands and the ankles of both feet. The skin and the electrodes were pre-cleaned and dried prior to use. Reliability of the InBody S10 has previously been shown to be high within and between users but may underestimate body fat mass [19]. With Inbody S10 basal metabolic rate (BMR) was estimated by using the regression equation $\mathrm{BMR}=370+21.6 \times$ FFM (fat-free mass).

\subsubsection{Pre-Attempt Laboratory Testing}

Prior to the world record attempt, SG completed a $\mathrm{VO}_{2}$ max test to assess her maximum oxygen uptake and lactate threshold. The test was performed on the same treadmill as used for the world record attempt (Quasar, $\mathrm{H} / \mathrm{P} /$ Cosmos, $\mathrm{H} / \mathrm{P} / \mathrm{Cosmos}$ Sports and Medical GMBH, Germany). The athlete started running at $11 \mathrm{~km} / \mathrm{h}$ and a gradient of $1 \%$. The speed was increased by $1 \mathrm{~km} / \mathrm{h}$ every $3 \mathrm{~min}$ until the speed could no longer be maintained, i.e., volitional exhaustion [20]. Breath-by-breath measures of $\mathrm{VO}_{2}$, and carbon dioxide output $\left(\mathrm{VCO}_{2}\right)$ were measured continuously (Piston HD6000, nSpire, nSpire Health Inc, Hertford, UK). The gas analyser was calibrated according to the manufacturer's instructions with known gases, and the volume transducer was calibrated with a 3-litre calibration syringe (Hans Rudolph 5530, Shawnee, OH, USA). Heart rate was measured continuously by telemetry and noted down in the last minute of every stage (PE4000, Polar Electro Oy, Kempele, Finland) when a steady-state HR was reached. At the end of every stage the athlete straddled the treadmill, and a fingertip blood sample was taken for immediate analysis of blood lactate (Ysi, 2300 Lactate and Glucose, Ysi UK Ltd., Hampshire, UK).

\subsubsection{Cardio-Respiratory, Heart Rate and Subjective Measures}

A heart rate monitor was worn continuously (PE4000, Polar Electro Oy, Kempele, Finland) and heart rate was measured once in the final minutes each hour. $\mathrm{VO}_{2}$ was collected for $2 \mathrm{~min}$ in the final stages of each marathon using a breath by breath online portable gas analyser (MetaMax 3b, Cortex $\mathrm{GmbH}$, Leipzig, Germany). The record was completed on a standard treadmill (Quasar, $\mathrm{H} / \mathrm{P} / \mathrm{Cosmos}, \mathrm{H} / \mathrm{P} / \mathrm{Cosmos}$ Sports and Medical GMBH, Germany) situated in the open area of the Olympia building of Teesside University in the UK. The average of each 2-min sample was calculated from the raw, unfiltered, breath by breath data. From measures of $\mathrm{VCO}_{2}$ and $\mathrm{VO}_{2}$, total carbohydrate 
$(\mathrm{CHO})$ and fat oxidation rates were calculated using the formulas of Frayn [21], assuming negligible protein oxidation:

$$
\begin{aligned}
& \text { Total fat oxidation }\left(\mathrm{g} / \mathrm{min}^{-1}\right)=1.67 * \mathrm{VO}_{2}-1.67 * \mathrm{VCO}_{2} \\
& \text { Total CHO oxidation }\left(\mathrm{g} / \mathrm{min}^{-1}\right)=4.55 * \mathrm{VCO}_{2}-3.21 * \mathrm{VO}_{2}
\end{aligned}
$$

Rating of perceived exertion (RPE) was assessed via the CR-10 scale [22]. RPE was recorded every hour. Arbitrary units are reported with accompanying verbal descriptors.

\subsubsection{Sleep and Lung Function}

Resting HR and sleep metrics were tracked throughout via Garmin Vivoactive (Garmin International, Olathe, KS, USA). As SG is asthmatic, peak flow rate (PFR) and peak expiratory flow (PEF) were measured every morning upon waking (Vitalograph, Lenexa, KS, USA).

\subsubsection{Haematology and Body Composition}

All blood samples were taken pre and post every marathon from a fingertip capillary from the ring finger of the left hand, prior to analysis. Blood lactate $\left(\mathrm{mmol} . \mathrm{L}^{-1}\right),(\mathrm{Ysi}$, 2300 Lactate and Glucose, Ysi UK Ltd., Hampshire, UK), haemoglobin (g.dl) (Prospect $\mathrm{Hb}$, Diaspect Medial GMBH, Von-cancrin-str1, 63,877 Salauf, Germany), glucose (mmol. ${ }^{-1}$ ) (NESCO multicheck, Kernel int'l Corp, Taiwan) and cholesterol levels (HDL, LDL, Trig; Mission Cholesterol Meter, Acon Labs Inc, 10,125 Mesa Rim Road, San Diego, CA, USA).

Samples for haematocrit (\%Hct) were collected in heparinised glass tubes and spun for $5 \mathrm{~min}$ at 14,000 rpm (Haemotrocit Centrifuge, Sigma, 1-14, Sigma Laboratories, D37520 Osterode am Harz, Germany). Spun blood was analysed using a Hawksley micro haematocrit reader (Hawksley, Lancing, Sussex, UK).

\subsubsection{Nutritional Intake}

Nutritional intake was recorded in a detailed diary during the attempt, and the intake was analysed for total energy (kcal) and intakes for macronutrients per day using specialist software (Nutritics v.x, Nutritics, Dublin, Ireland). Relative intake $\left(\mathrm{g} \cdot \mathrm{kg}^{-1}\right)$ was also calculated for comparison to sports nutrition guidelines and previous research.

\subsection{Other Recovery Measures}

Following the post-run blood and body composition measures the athlete had an ice bath for her feet and a massage every day.

\subsection{Statistical Analysis}

Data are reported as both means \pm standard deviations and per marathon (Figures 1-4; Tables 1 and 2). Data were stored, compiled and analysed in Microsoft Excel (v16.39; 2020; Microsoft, Redmond, Washington, DC, USA) due to the relatively simplistic approach to statistical testing employed. 


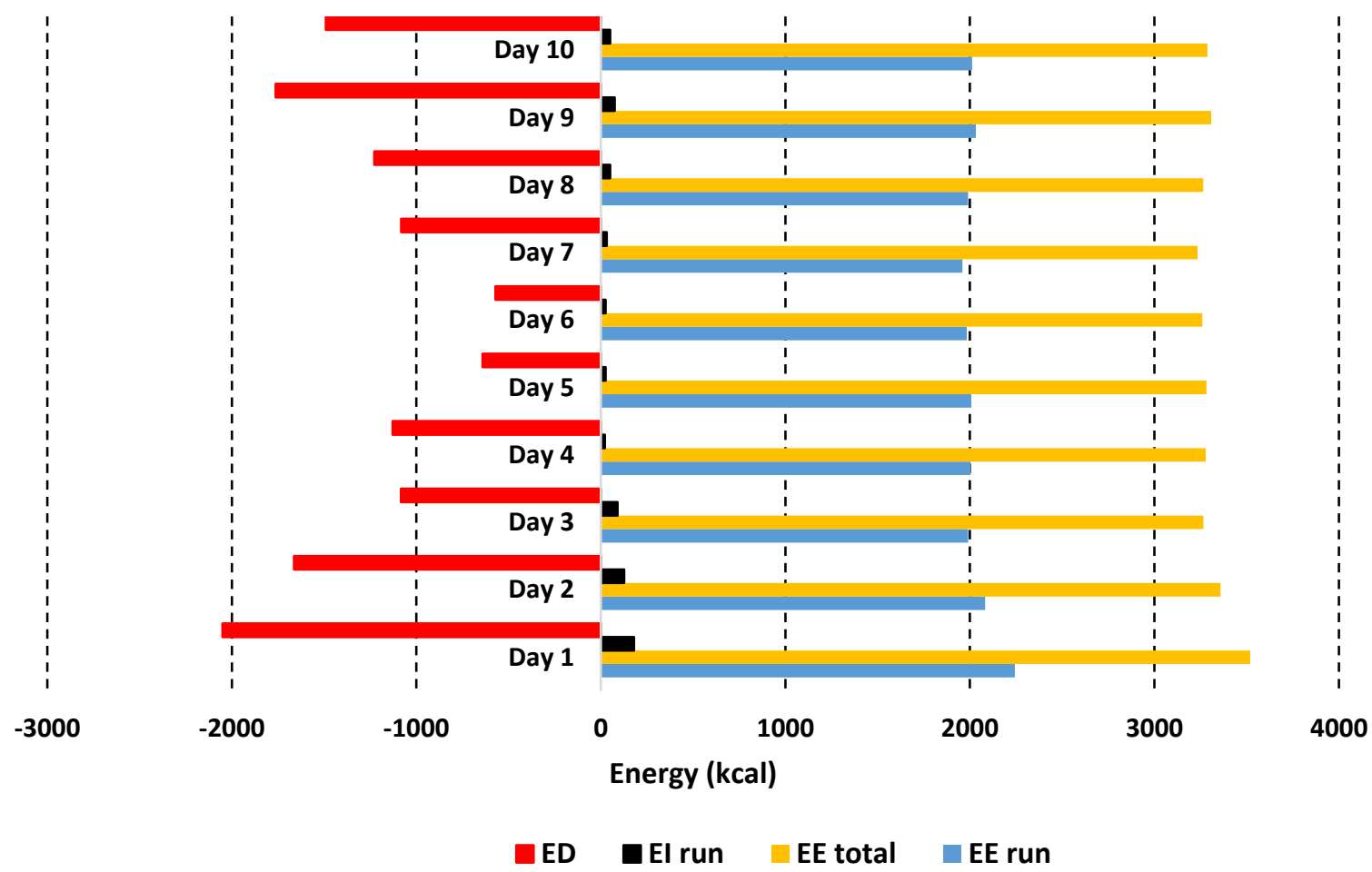

Figure 1. Energy intake (EI), energy expenditure (EE) and energy deficit (ED). Please note that the overall EI matches the EE during the runs, but overall, there is a significant ED every day due to EE from BMR and other activities.

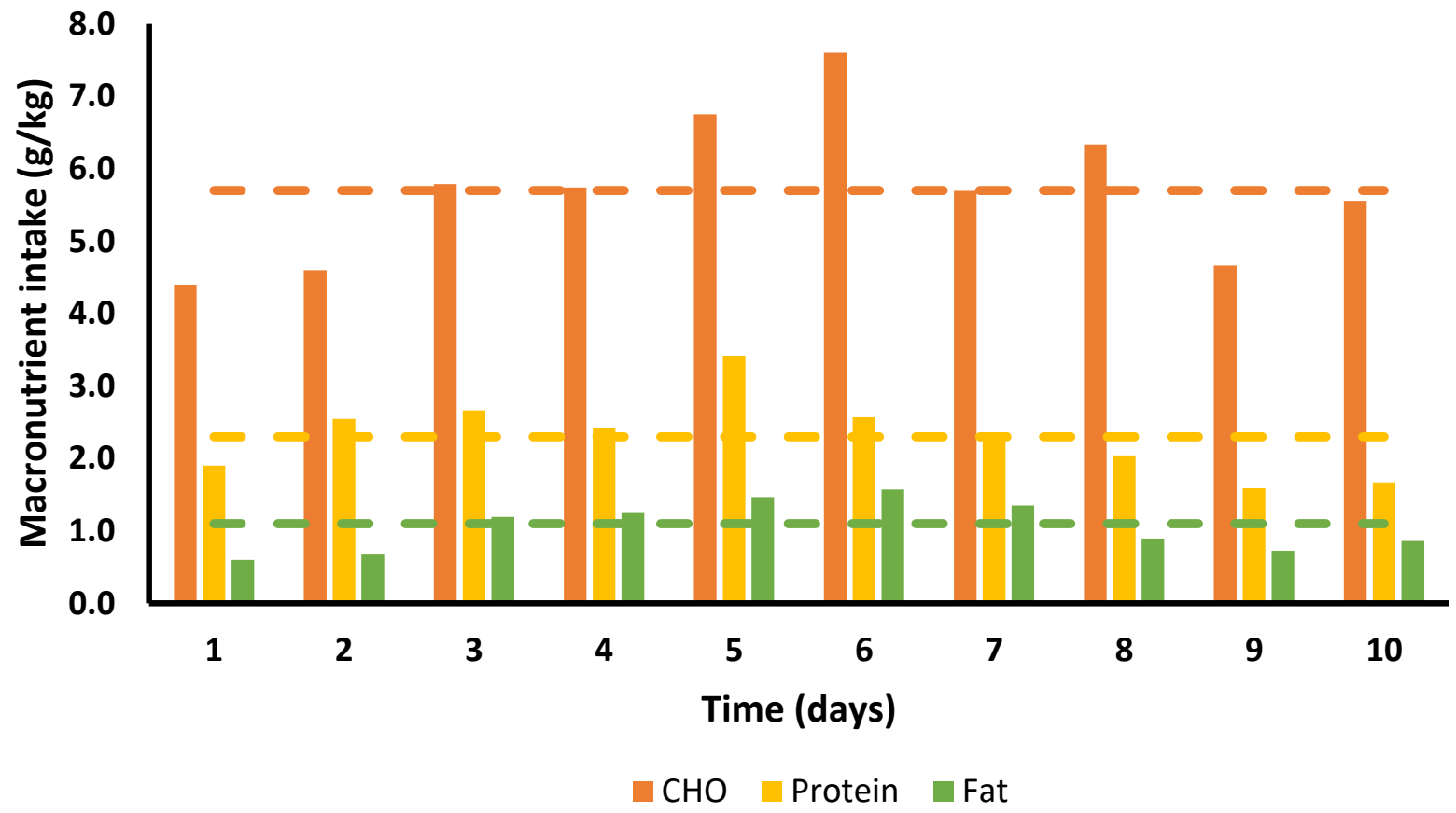

Figure 2. Daily macronutrient intake in grams per kg body mass. Bars represent individual macronutrient intake per day; dashed lines correspond to mean intake for each macronutrient. 


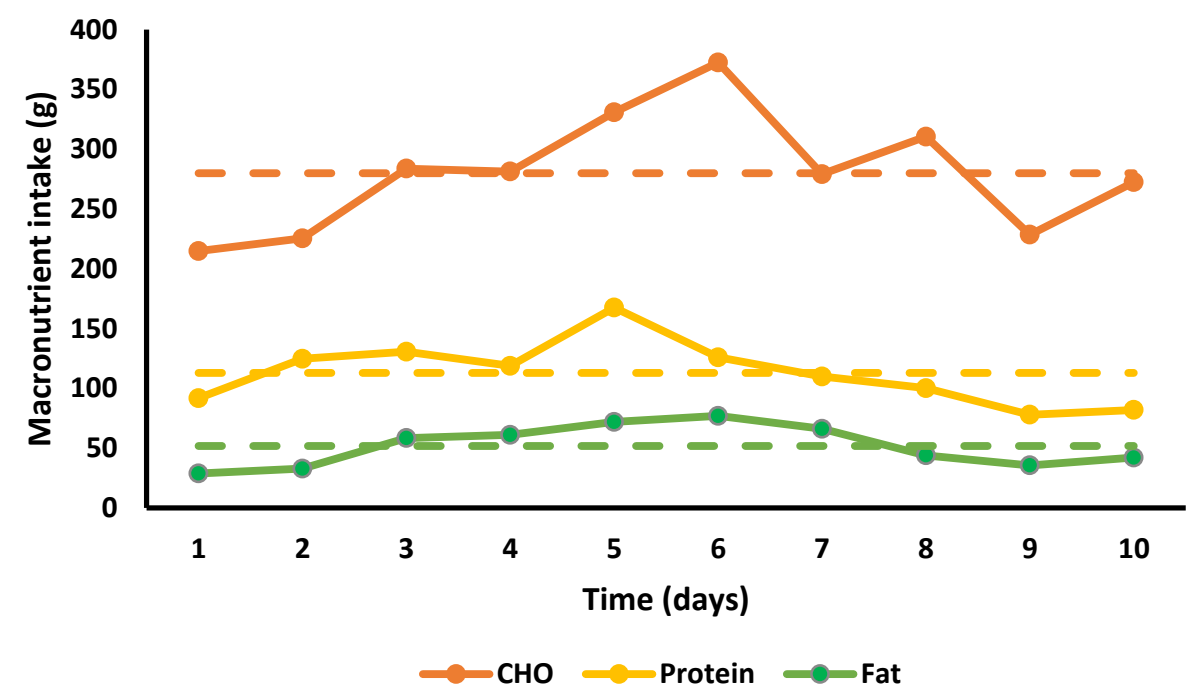

Figure 3. Total macronutrient intake in grams. Series lines link individual data points for the intake of each macronutrient $(\mathrm{g})$ per day. Dashed lines represent the mean intake for each macronutrient across all 10 days.

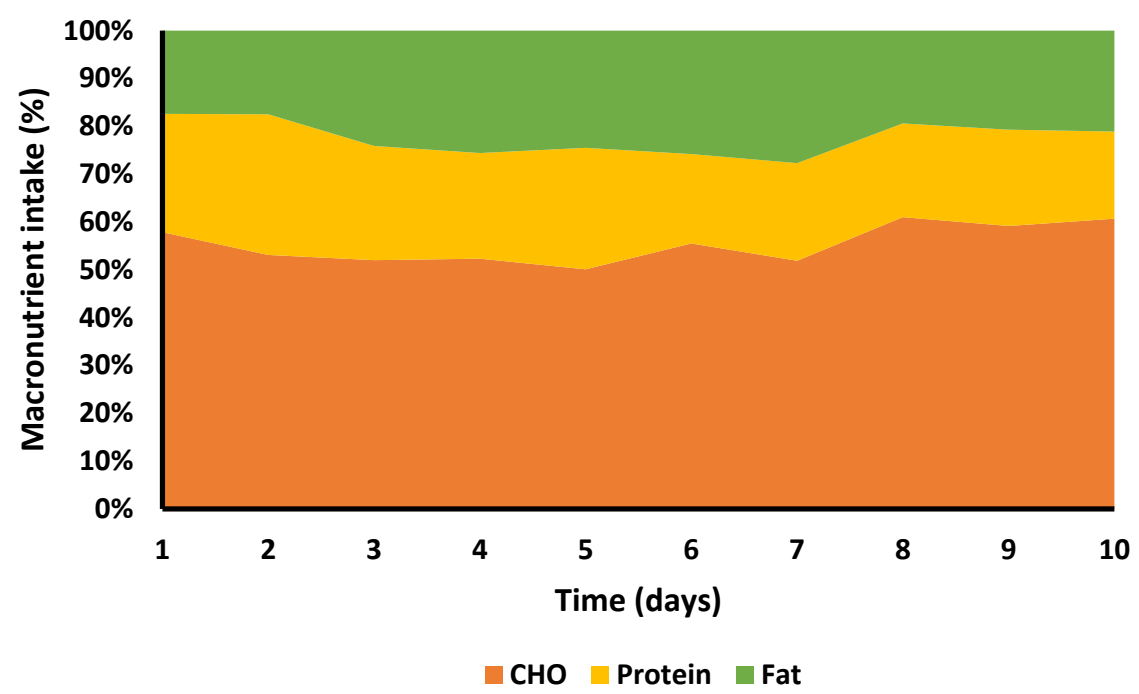

Figure 4. Percentage macronutrient contribution. Please note that mean carbohydrate contribution is $55 \%$ of total intake.

Table 1. Completion times for all 10 Marathons.

\begin{tabular}{|c|c|}
\hline Marathon & $\begin{array}{l}\text { Completion Time } \\
\text { (h, min, s) }\end{array}$ \\
\hline 1 & $4 \mathrm{~h} 21 \min 21 \mathrm{~s}$ \\
\hline 2 & $4 \mathrm{~h} 21 \min 39 \mathrm{~s}$ \\
\hline 3 & $4 \mathrm{~h} 24 \min 38 \mathrm{~s}$ \\
\hline 4 & $4 \mathrm{~h} 24 \mathrm{~min} 06 \mathrm{~s}$ \\
\hline 5 & $4 \mathrm{~h} 23 \min 55 \mathrm{~s}$ \\
\hline 6 & $4 \mathrm{~h} 24 \min 22 \mathrm{~s}$ \\
\hline 7 & $4 \mathrm{~h} 23 \min 54 \mathrm{~s}$ \\
\hline 8 & $4 \mathrm{~h} 23 \min 21 \mathrm{~s}$ \\
\hline 9 & $4 \mathrm{~h} 23 \min 25 \mathrm{~s}$ \\
\hline 10 & $4 \mathrm{~h} 21 \min 21 \mathrm{~s}$ \\
\hline Mean ${ }^{1}$ & $4 \mathrm{~h} 23 \min 9 \mathrm{~s}$ \\
\hline Total & $43 \mathrm{~h} 51 \mathrm{~min} 39 \mathrm{~s}$ \\
\hline
\end{tabular}

${ }^{1}$ Please note the consistent finishing times, varying by just 3 min between attempts. 
Table 2. Heart rate for all 10 marathons.

\begin{tabular}{cc}
\hline Marathon & $\begin{array}{c}\text { Heart Rate } \pm \text { SD } \\
\text { (b.min } \mathbf{- 1})\end{array}$ \\
\hline 1 & $139 \pm 10$ \\
2 & $140 \pm 5$ \\
3 & $136 \pm 9$ \\
4 & $146 \pm 5$ \\
5 & $148 \pm 10$ \\
6 & $142 \pm 4$ \\
7 & $141 \pm 7$ \\
8 & $142 \pm 9$ \\
9 & $150 \pm 8$ \\
10 & $144 \pm 6$ \\
Mean ${ }^{2}$ & $143 \pm 4$ \\
\hline 2 Please note the highly consistent heart for all 10 marathons attempts. Only days 5 and 9 are slightly elevated
\end{tabular}
compared to the mean.

\section{Results}

\subsection{Laboratory Testing before the Attempt}

In November 2017, SG was $162.5 \mathrm{~cm}$, weighed $49.3 \mathrm{~kg}$ and reached a top running speed of $16 \mathrm{~km} / \mathrm{h}$. Her was $\mathrm{VO}_{2} \max 53 \mathrm{~mL} / \mathrm{kg}^{-1} / \mathrm{min}^{-1}\left(2.59 \mathrm{~L} / \mathrm{min}^{-1}\right)$, with her lactate threshold occurring at $75 \%$ of $\mathrm{VO}_{2}$ max. Her maximal heart rate was $174 \mathrm{~b} \cdot \mathrm{min}^{-1}$.

\subsection{Record Breaking Performance}

SG set out to beat the previous record and targeted sub $45 \mathrm{~h}$. SG completed 10 marathons in 10 consecutive days in a total time of $43 \mathrm{~h} 51 \mathrm{~min} 39 \mathrm{~s}$, breaking the previous world record of $46 \mathrm{~h} 15 \mathrm{~min}$ by $2 \mathrm{~h} 24 \mathrm{~min}$, running $2.5 \mathrm{~h}$ faster than the previous record. She ran consistently at $9.2-9.7 \mathrm{~km} / \mathrm{h}$ and varied her speed by $0.1-0.3 \mathrm{~km} / \mathrm{h}$ every $\sim 10 \mathrm{~min}$ (see Table 1 for individual marathon times).

\subsection{Body Composition}

Pre attempt to post attempt SG's weight decreased from $51 \mathrm{~kg}$ to $48.4 \mathrm{~kg}$, bodyfat mass decreased from $9.1 \mathrm{~kg}$ to $7.2 \mathrm{~kg}$, bodyfat percent decreased from $17.9 \%$ to $14.8 \%$, muscle mass decreased from $23.2 \mathrm{~kg}$ to $22.8 \mathrm{~kg}$. Body mass decreased by $2.6 \mathrm{~kg}$ at the end of the event $(-5 \%)$, with an average daily loss of $0.9 \pm 0.3 \mathrm{~kg}$, or $1.8 \%$ total body weight. Skeletal muscle mass decreased by $0.4 \mathrm{~kg}$ at the end of the event $(-1.72 \%)$, body fat mass decreased by $1.9 \mathrm{~kg}(-20.88 \%)$, percent body fat decreased by $3.1 \%(-17.32 \%)$, and visceral fat decreased by $8 \mathrm{~cm}^{2}(-25.81 \%)$. Intracellular and extracellular water showed little change and decreased by $0.3 \%(-1.55 \%$ total $)$ and $0.2 \%(-1.77 \%$ total $)$, respectively.

\subsection{Heart Rate}

Mean HR for all marathons combined was $143 \pm 4$ b.min ${ }^{-1}$. For all 10 marathons combined heart rate was similar between the 1st and 2nd hours before increasing in the 3rd and 4 th hours for each marathon, on average these increases were $4-5 \%$ in both instances (see Tables 2 and 3 for detailed heart rate data).

Table 3. Average heart rate per hour of marathon for all 10 marathons.

\begin{tabular}{cc}
\hline Hour of Marathon & $\begin{array}{c}\text { Heart Rate } \pm \text { SD } \\
\text { (b.min }^{-1} \text { ) }\end{array}$ \\
\hline 1 & $137 \pm 6$ \\
2 & $137 \pm 5$ \\
$3^{3}$ & $145 \pm 6$ \\
4 & $151 \pm 5$ \\
Mean & $143 \pm 4$ \\
\hline
\end{tabular}

${ }^{3}$ Please note that despite the even pace there is a noticeable increase in heart rate from the 3rd hour. 


\subsection{Sleep and Resting Heart Rate}

SG's resting HR increased slightly from $51 \mathrm{~b} \cdot \mathrm{min}^{-1}$ on the first day to $53-57 \mathrm{~b} . \mathrm{min}^{-1}$ on the remaining days. Her average resting HR was $54 \pm 1.6$ b. $\min ^{-1}$. Mean sleep time was $500.6 \pm 55.7 \mathrm{~min}$ ( $8 \mathrm{~h} 20 \mathrm{~min}$ ), with the longest sleep time $9 \mathrm{~h} 47 \mathrm{~min}$ on day 7, and the shortest $6 \mathrm{~h} 50 \mathrm{~min}$ on day 4 . The time spent in deep sleep fluctuated from a peak $3 \mathrm{~h}$ 33 min on day 10 , and the shortest was 1 h 0 min on day 8 .

\subsection{Lung Function, Oxygen Uptake and Energy Expenditure}

Peak flow rate (PFR)/peak expiratory flow (PEF) decreased slightly, with a mean PFR/PEF of $379 \pm 18.1 \mathrm{~L} / \mathrm{min}^{-1}$, and the highest PFR of $410 \mathrm{~L} / \mathrm{min}^{-1}$ on day 1 and the lowest of $350 \mathrm{~L} / \mathrm{min}^{-1}$ on days 2 and day 6 .

$\mathrm{VO}_{2}$ was similar for all 10 marathons at $1.6 \pm 0.1 \mathrm{~L} \cdot \mathrm{min}^{-1} / 32.3 \pm 1.1 \mathrm{~mL} \cdot \mathrm{kg}^{-1} \cdot \mathrm{min}^{-1}$. With a $\mathrm{VO}_{2}$ max of $53 \mathrm{~mL} / \mathrm{kg}^{-1} / \mathrm{min}^{-1} / 2.588 \mathrm{~L} / \mathrm{min}^{-1}$, SG worked at $\sim 60 \%$ of her $\mathrm{VO}_{2}$ max during every marathon.

Basal metabolic rate (BMR) was calculated as $1274 \mathrm{kcal}$ via BIA. Energy expenditure (EE) averaged $2030 \pm 82 \mathrm{kcal} /$ marathon and thus totalled of 20,306 kcal for all 10 marathons. Her average RER was $0.8 \pm 0$ and, therefore, $33.4 \%$ of calories came from carbohydrate (CHO), $66.6 \%$ came from fat oxidation. She utilised $157 \pm 6 \mathrm{~g}$ of $\mathrm{CHO}$ and $147 \pm 6 \mathrm{~g}$ of fat during each marathon and metabolised a total of $1570 \mathrm{~g}$ of $\mathrm{CHO}$ and $1468 \mathrm{~g}$ of fat.

Mean daily energy intake (EI) was $2036 \pm 418 \mathrm{kcal}$, with total 20,356 kcal over the 7 days. EI almost exactly matched EE from the marathons but did not match total daily EE including basal metabolic rate of $1274 \mathrm{kcal}$. Total overall EE including marathons and BMR was $33,056 \mathrm{kcal}$, leading to an energy deficit (ED) of $-12,700 \mathrm{kcal}$.

\subsection{Nutritional Intake}

Energy and absolute and relative macronutrient intakes for each day of the 10 days are presented in Figures 1 and 2; Table 4 provides an example of the nutritional intake for a single day.

Calorie consumption during each run decreased significantly after the first two days due to complaints of nausea. Nausea was treated with motion sickness medication (day 1 and 2; Cinnarizine) and pressure point wrist bands for the remaining days. On days 1 and 2, SG consumed a carbohydrate solution with a small amount of added protein (day 1: $180 \mathrm{kcal}$; day 2: $126 \mathrm{kcal}$ ). The following 8 days she only consumed plain water and 11-25 grapes during each run, with a mean of $46.4 \pm 25 \mathrm{kcal} /$ marathon, a total of $371 \mathrm{kcal}$ from grapes. For all 10 days the calories consumed during the runs were $67.7 \pm 51.5 \mathrm{kcal} /$ day: a total intake of $676.5 \mathrm{kcal}$.

The mean daily total calorie consumption over the 10 days was $2035.6 \pm 418.4 \mathrm{kcal}$, with the lowest overall intake on day 1 with $1468 \mathrm{kcal}$ and the highest on day 6 with $2688 \mathrm{kcal}$. EE was $2030 \pm 82 \mathrm{kcal} /$ marathon, total EE for 10 days (including BMR) was $33,056 \mathrm{kcal}$, daily EI $2036 \pm 418 \mathrm{kcal}(20,356 \mathrm{kcal}$ total), resulting an ED of 12,700 kcal (Figure 1). Average intake was 279.9 g.day ${ }^{-1}$ for $\mathrm{CHO}\left(5.7 \mathrm{~g} . \mathrm{kg}^{-1}\right), 112.9 \mathrm{~g} \mathrm{day}^{-1}$ protein $\left(2.3 \mathrm{~g} . \mathrm{kg}^{-1}\right)$, and $51.8 \mathrm{~g}$ day $^{-1}$ fat $\left(1.1{\mathrm{~g} . \mathrm{kg}^{-1}}^{-1}\right.$ (Figures 2 and 3). Overall, $55 \%$ of calories consumed came from $\mathrm{CHO}, 22.2 \%$ came from protein and $22.9 \%$ came from fat (Figure 4 ).

Fluid intake was consistent over the 10 days at $4134 \pm 313 \mathrm{~mL} /$ day, divided into $2309 \pm 280 \mathrm{~mL} /$ day when not running and $1825 \pm 206 \mathrm{~mL} /$ day when running. While running, in the first 3 days fluid intakes were $2250 \mathrm{~mL}, 2000 \mathrm{~mL}$ and $2000 \mathrm{~mL}$, after which it reduced to $1750 \mathrm{~mL}$ every day, apart from day 8 when it reduced to $1500 \mathrm{~mL}$. The decrease was due to the cessation of CHO solution consumption. In total, SG consumed $41,340 \mathrm{~mL}$ over the 10 days: $23,090 \mathrm{~mL}$ when not running and $18,250 \mathrm{~mL}$ when running. 
Table 4. Example food and drink for a typical day.

\begin{tabular}{|c|c|}
\hline \multicolumn{2}{|l|}{ Breakfast } \\
\hline Weetabix (oats) & 2 \\
\hline Semi skimmed milk & $100 \mathrm{~mL}$ \\
\hline Sugar & 2 teaspoons \\
\hline Tea & $200 \mathrm{~mL}$ \\
\hline Coffee (instant) & $200 \mathrm{~mL}$ \\
\hline Actimel probiotic yoghurt & $100 \mathrm{~mL}$ \\
\hline \multicolumn{2}{|l|}{10 a.m. } \\
\hline Chicken cup soup & 1 \\
\hline Bread, whole meal & 1 slice \\
\hline \multicolumn{2}{|l|}{ Event } \\
\hline Grapes & 16 \\
\hline Water & $1750 \mathrm{~mL}$ \\
\hline \multicolumn{2}{|l|}{ Post-marathon } \\
\hline Semi skimmed milk & $500 \mathrm{~mL}$ \\
\hline Mountain fuel recovery powder & 2 scoops \\
\hline Neovite colostrum powder & 1 teaspoon \\
\hline Protein PHD pharma whey protein & $35 \mathrm{~g}$ \\
\hline Banana & 1 \\
\hline \multicolumn{2}{|l|}{ Evening } \\
\hline \multirow{3}{*}{\multicolumn{2}{|c|}{$\begin{array}{c}\text { lamb, roast potatoes, parsnips, carrots, green } \\
\text { beans, leaks, gravy } \\
\text { apple crumble and double cream }\end{array}$}} \\
\hline & \\
\hline & \\
\hline Tea & $600 \mathrm{~mL}$ \\
\hline \multicolumn{2}{|l|}{ Bed } \\
\hline Milk & $200 \mathrm{~mL}$ \\
\hline Sugar & 1 teaspoon \\
\hline Instant drinking chocolate & 1 teaspoon \\
\hline
\end{tabular}

\subsection{Haematology}

Haemoglobin $(\mathrm{Hb})$ was 13.2 g.dl and haematocrit (Hct) were $39 \%$ on day 1 . On average, $\mathrm{Hb}$ increased from $13.2 \pm 0.5$ g.dl to $13.7 \pm 0.6$ g.dl, ( $3.6 \%$ increase), and Hct increased from $38.6 \pm 1.0 \%$ to $40.2 \pm 1.2 \%$ ( $4.2 \%$ increase). $24 \mathrm{~h}$ post completion $\mathrm{Hb}$ was 11.4 g.dl, and Hct $37 \%$, and 7 days post event $\mathrm{Hb}$ was 13.9 g.dl and Hct was $42 \%$.

Blood lactate prior to starting each marathon was $1.1 \pm 0.3 \mathrm{mmol} . \mathrm{L}^{-1}$ and post was $1.3 \pm 0.3 \mathrm{mmol} . \mathrm{L}^{-1}$, demonstrating a negligible excursion of $0.2 \mathrm{mmol} . \mathrm{L}^{-1}$ pre to post for all 10 marathons.

Blood glucose remained within normal range pre to post for each marathon, dropping from $6.1 \pm 1.0 \mathrm{mmol} . \mathrm{L}^{-1}$ to $5.4 \pm 0.4 \mathrm{mmol} . \mathrm{L}^{-1}$, a change of $9.9 \% .24 \mathrm{~h}$ post glucose was $6.0 \mathrm{mmol} . \mathrm{L}^{-1}$ and 7 days post it was $4.5 \mathrm{mmol} . \mathrm{L}^{-1}$.

LDL cholesterol decreased pre to post for all 10 days from $2.3 \pm 0.3 \mathrm{mmol} . \mathrm{L}^{-1}$ to $1.8 \pm 0.4 \mathrm{mmol} . \mathrm{L}^{-1}$ (20.7\% decrease). $24 \mathrm{~h}$ post LDL was $2.59 \mathrm{mmol} . \mathrm{L}^{-1}$ and 7 days post was $3.98 \mathrm{mmol} . \mathrm{L}^{-1}$. HDL increased trivially pre to post for all 10 days from $2.1 \pm 0.2 \mathrm{mmol} . \mathrm{L}^{-1}$ to $2.2 \pm 0.2 \mathrm{mmol} . \mathrm{L}^{-1},(6 \%$ increase $)$, and continued to decrease $24 \mathrm{~h}$ post $\left(1.97 \mathrm{mmol} . \mathrm{L}^{-1}\right)$ and 7 days post $\left(1.47 \mathrm{mmol} . \mathrm{L}^{-1}\right)$. Triglycerides increased markedly pre to post for all 10 days from $0.8 \pm 0.1 \mathrm{mmol} . \mathrm{L}^{-1}$ to $1.9 \pm 0.3 \mathrm{mmol}^{-1} \mathrm{~L}^{-1}$ (133.4\% increase). $24 \mathrm{~h}$ post triglycerides were $1 \mathrm{mmol} . \mathrm{L}^{-1}$ and 7 days post they were $1.63 \mathrm{mmol} . \mathrm{L}^{-1}$.

\subsection{Subjective Measures}

RPE remained stable throughout the 10 days, with a mean rating of $5.0 \pm 0.0$ arbitrary units for the first hour, $5.0 \pm 0.16$ for the second hour, $5.17 \pm 0.35$ for the third hour and $5.56 \pm 0.46$ for the fourth hour of every day; the equivalent verbal descriptor of an RPE of 5 is Hard [19]. 


\section{Discussion}

The aim of this study was to analyse the energy intake (EI), energy expenditure (EE) and subsequent energy deficit (ED), and track the changes in body composition and haematology, over the course of 10 marathons $(421.95 \mathrm{~km})$ ran on consecutive days. We also set out to describe the ideal strategy necessary to set a successful world record (WR). The previous WR of $46 \mathrm{~h} 15 \mathrm{~min}$ was improved by 2.5 h and SG completed the event in $43 \mathrm{~h} 51 \mathrm{~min} 39 \mathrm{~s}$.

The main finding from this study was that SG was in a daily ED of $1270 \mathrm{kcal}$, with a total ED of 12,700 kcal over the 10 days. As a result, SG lost $0.4 \mathrm{~kg}$ of skeletal muscle mass and $1.9 \mathrm{~kg}$ bodyfat mass. The fact that she consumed limited nutrition during the marathons exacerbated the ED and the loss of body mass but served to minimise nausea and thus potential gastrointestinal distress. The second finding was that the successful strategy SG adopted was a highly consistent pacing strategy and followed a set recovery regime, which included sleeping for an average of $8 \mathrm{~h} 20 \mathrm{~min}$ each night and emphasising dietary carbohydrate intake between marathons. She completed each marathon in between $4 \mathrm{~h} 21 \mathrm{~min}$ and $4 \mathrm{~h} 24 \mathrm{~min}$. She ran unfailingly at $9.2-9.7 \mathrm{~km} / \mathrm{h}$ and varied her speed by $0.1-0.3 \mathrm{~km} / \mathrm{h}$ at approximately $10 \mathrm{~min}$ intervals to ensure a small change in pace and to relieve monotony. Each marathon was followed by a protein and carbohydrate recovery drink and a massage [19].

\subsection{Nutritional Intake and Energy Deficit}

Recommendations for $\mathrm{CHO}$ intake in highly active athletes are 5-8 g/ kg/day $[23,24]$. SG fulfilled this recommendation by consuming $5.7 \pm 1.0 \mathrm{~g} / \mathrm{kg} /$ day, although recommendations for those in high volume intense activity of 3-6 h/day may need to consume as much as $8-10 \mathrm{~g} / \mathrm{kg} /$ day $[23,24]$. The dietary recommendations for fat for athletes are similar to those for non-athletes in promoting health, constituting $\sim 30 \%$ of daily caloric intake [25]. SG only consumed $22.9 \%(1.1 \pm 0.4 \mathrm{~g} / \mathrm{kg} /$ day $)$ of her total calories from fat, although this is not surprising as she was purposefully emphasising high $\mathrm{CHO}$ and protein foods.

Although SG set out to consume $\mathrm{CHO}$ throughout the attempt in the form of $\mathrm{CHO}$ drinks, smoothies, sweets (jellybeans) and solid food (sandwiches), she complained of GI distress, and significantly altered her nutrition strategy to include almost no food (a small number of grapes) and only plain water after the first two marathons. During the first two marathons, despite the available selection of food and drink, she did not eat any solid food, and only consumed a carbohydrate solution $(\sim 150 \mathrm{kcal})$ in addition to water. Following her nausea, she altered her nutrition strategy again for the following 8 marathons. During each marathon EI was minimal (mean $68 \pm 51 \mathrm{kcal} /$ marathon from grapes), instead relying on increasing her EI before and after each run.

It has been suggested that athletes ingest up to $90 \mathrm{~g} / \mathrm{h}$ of $\mathrm{CHO}$ during activities lasting longer than $2.5 \mathrm{~h}[26,27]$. This is especially important when competing back-to-back over several days [28]. Indeed, a recent study by Viribay and colleagues [29] demonstrated that an even higher intake of $120 \mathrm{~g} / \mathrm{h}$ could limit exercise-induced muscle damage and shorten recovery time, but the gastrointestinal burden of consuming such a high intake likely requires a comprehensive nutritional training strategy $[26,30,31]$ and resultant phenotypic adaptations within the gut. Such high doses have also been reported in cycling [32], but cycling lacks the mechanical load imparted by running, thus facilitating high rates of $\mathrm{CHO}$ consumption with lesser risk to inducing GI symptoms, as experienced by SG during the present attempt. SG employed a similar low-CHO-intake strategy during a previously successful world-record attempt [33].

GI complaints are very common in runners, especially those competing over longer distances, with $30-50 \%$ being reported in marathon running, $83 \%$ at $60 \mathrm{~km}$, and up to $96 \%$ in a $161 \mathrm{~km}$ ultramarathon [8]. These symptoms may be responsible for race withdrawal and a failure to attain planned nutritional strategies [34]. SG complained of nausea during the 2nd and 3rd day and had to reduce her running speed as she thought she might vomit. 
Following this she took sea sickness tablets (Sturgeon; Cinnarizine $15 \mathrm{mg}$ ) and also wore wrist bands that are alleged to provide acupressure to reduce nausea. From the 5th day onwards, she only wore the wrist bands and no longer took any medication. The nausea seemed to be caused by the carbohydrate drink, but also due to the motion of the treadmill, and as a precaution she only consumed plain water from days 3-10.

Recommendations for protein intake for athletes involved in moderate amounts of exercise are 1.2-2.0 g/ kg/day and slightly higher for athletes involved in high volume or intense exercise, who should consume 1.7-2.2 g/ kg/day [18,35,36]. In addition, recommendations for older athletes are for single doses of $40 \mathrm{~g}$, especially post-exercise, as older musculature responds more slowly and has lower sensitivity to protein ingestion [37-39]. SG's mean protein intake was $2.3 \pm 0.5 \mathrm{~g} / \mathrm{kg} /$ day, satisfying the recommended daily intake. She achieved this with the addition of protein drinks immediately post-marathon, followed by a large protein bolus at her evening meals. Despite this adequate protein supply, she still lost $1.2 \mathrm{~kg}$ in total bodyweight and $0.3 \mathrm{~kg}$ of muscle mass. Although we typically assume minimal contribution from protein as an energy source during exercise, these data suggest that protein oxidation took place to the extent that body composition was affected $[40,41]$. It is unclear whether this increase in protein contribution to metabolism occurred during or between marathons and would have likely been exacerbated by SG's accumulation of a large ED, but partially offset by the exercise stimulus and EI.

The majority of performance and practices associated with the attempt were the athlete's choice alone; it is important to note however, that SG is an incredibly experienced ultra-athlete and also engages with sports science literature to support her decision making. SG's blended use of both tacit and explicit evidence is considered evidence-informed performance. We believe as sports scientists involved in supporting the documented attempt, our role was to assess, analyse, and where appropriate, inform the athlete's choices, but not to interfere with or direct performance or decision making for the sake of publication.

\subsection{Body Composition Changes}

From the baseline measure before the first marathon to completion of the tenth marathon, SG's body mass decreased by $2.6 \mathrm{~kg}(-5 \%)$, with an average daily loss of $0.9 \pm 0.3 \mathrm{~kg}$ (1.8\% total body weight). Using BIA, we measured decreases in skeletal muscle mass $(0.4 \mathrm{~kg} ;-1.72 \%)$, body fat mass $(1.9 \mathrm{~kg} ;-20.88 \%)$, percent body fat $(3.1 \% ;-17.32 \%)$, and visceral fat $\left(-8 \mathrm{~cm}^{2} ;-25.81 \%\right.$ change from pre-event) from the first to the tenth day. We can be relatively confident in these results as the InBody S10 has been shown to be a valid measure of lean body mass and body fat mass in comparison to dual-energy X-ray absorptiometry [39] and is considered highly reliable when used by the same assessor (ICC: 0.89; 95\% CI: 0.86-0.92; [42,43]).

In a 5-day, $339 \mathrm{~km}$ race Knechtle et al. [4] found no reduction in body mass or fat mass but reported a similar reduction in skeletal muscle mass of $0.63 \pm 0.79 \mathrm{~kg}$ at the end of the race. This is likely due to the fact that competitors during this event consumed more calories during the event and sustained a much smaller ED than SG.

The results suggest a high contribution from endogenous fat stores towards energy metabolism and a small amount of protein catabolism [44]; this is further supported by SG's negligible EI during the marathon's, as fasted training has been shown to increase fat oxidation and branched-chain amino acid oxidation, concomitantly elevating protein catabolism $[45,46]$.

Intracellular and extracellular water remained mostly stable following each marathon and decreased by $0.3 \%(-1.55 \%$ total $)$ and $0.2 \%(-1.77 \%$ total $)$, respectively, indicating that fluid intake $(1825 \pm 206 \mathrm{~mL})$ during each run matched sweat rate accurately. SG is an experienced runner and had a very consistent fluid intake, equal to $456 \mathrm{~mL} / \mathrm{h}$ during each marathon. This is $\sim 50 \%$ more than reported for ad libitum water consumption during a $100 \mathrm{~km}$ race [47], suggesting SG drank to a plan, as opposed to drinking to thirst. Elite runners have been shown to ingest $550 \pm 340 \mathrm{~mL} / \mathrm{h}$ (range 30-1090 mL/h), which is above 
SG's consumption, despite a higher running pace throughout [48]. Lower fluid intakes may also be advantageous to avoid hyponatraemia e.g., Kipps et al. [49] reported fluid intakes ranging from $3683 \mathrm{~mL} / 843 \mathrm{~mL} / \mathrm{h}$ for hyponatraemic runners and $1924 \mathrm{~mL} / 451 \mathrm{~mL} / \mathrm{h}$ for those without hyponatraemia during the London marathon.

\subsection{Respiratory Variables}

It was reported that UR's have more allergies ( 25.1\%) and exercise-induced asthma $(\sim 13.0 \%)$ than the general population [50]. SG has pronounced exercise-induced asthma, which she controls with the appropriate medication. She recorded her peak flow rate (PFR) every morning before the start of each marathon, and there was a decrease from $410 \mathrm{~L} / \mathrm{min}^{-1}$ on day 1 to $350 \mathrm{~L} / \mathrm{min}^{-1}$ on days 2 and day 6 , with an average of $379 \pm 18.1 \mathrm{~L} / \mathrm{min}^{-1}$, although this minor change caused no problems in terms of health or performance.

SG exhibited a consistently low RER of $0.8 \pm 0$ throughout the attempt. Factors that can influence RER include diet, exercise intensity and duration, muscle glycogen content, proportion of type I muscle fibres, dietary fat intake, training status and blood metabolites (plasma lactate; serum FFA concentrations [44,51]). Fat oxidation increases from $\sim 35 \% \mathrm{VO}_{2}$ max to a maximal rate at an intensity of $48 \pm 1 \% \mathrm{VO}_{2} \max$ [44]. During low-intensity exercise lipids provide more than half of the energy contribution, and as exercise intensity increases, thus does the contribution from $\mathrm{CHO}$, and that from lipids decreases. The reported cross-over point reportedly lies between $48-53 \% \mathrm{VO}_{2}$ max, or at approx. $50 \%$ as suggested previously by others [52].

SG exercised at approx. $60 \% \mathrm{VO}_{2}$ max with a consistent RER of 0.80 , demonstrating a lower RER than previously described in untrained males (0.83-0.95; [53]), confirming a high contribution of fat metabolism towards energy production, despite an increased exercise intensity. There is considerable interindividual variation in substrate utilisation, even at comparatively low work rates e.g., Helge et al. [53] demonstrated that even at $55 \% \mathrm{VO}_{2}$ max the RER in untrained men varied from 0.83 to 0.95 . For trained persons and over a variety of work rates $(25,50$ and $70 \%$ peak power output) an even larger variability of $0.72-0.93$ was shown [51]. Greater variability than observed was expected in SG's measures given the presumably additive nature of the challenge, but her training status and phenotypic adaptations to years of ultra-running allowed for a predominantly fat derived effort, despite performing at a higher relative intensity than previous experimental work.

\subsection{Recovery Strategies}

Recovery between repeated endurance events is crucial. Strategies include rehydration, refuelling, massage, and sleep [28,54]. Immediately post-marathon (after post-exercise blood samples and body composition were recorded), SG consumed a carbohydrate and protein recovery drink with added colostrum while she had a massage. Massage has been shown to aid recovery, although not to improve performance [17]. SG chose to consume a large evening meal, followed by a dessert and protein and $\mathrm{CHO}$ rich milky drink before going to sleep to aid muscle repair, reduce DOMS and increase muscle and liver glycogen replenishment [18].

Sleeping sufficiently is also crucial to recovery [54], and although moderate amounts of exercise enhance sleep quality, high training or racing loads might negatively affect sleep and reduce the ability to recover adequately. Part of the strategy for a successful WR attempt was to maximise sleep and allow enhanced recovery. Sleep time and deep sleep were tracked with a wearable device (Garmin Vivoactive; Garmin, Olathe, KA, USA) and showed that SG slept for $500.6 \pm 55.7 \mathrm{~min} /$ day $(8 \mathrm{~h} 20 \mathrm{~min}$ ), with the longest sleep time $9 \mathrm{~h} 47 \mathrm{~min}$ on day 7 , and the shortest 6 h $50 \mathrm{~min}$ on day 4 . The time spent in deep sleep fluctuated from a peak $3 \mathrm{~h} 33 \mathrm{~min}$ on day 10 , and the shortest was $1 \mathrm{~h} 0 \mathrm{~min}$ on day 8 . Time spent asleep was longer than reported by Knufinke et al. [54] (7 h $50 \mathrm{~min}$ ) and especially deep sleep was far longer than the reported $1 \mathrm{~h} 36 \mathrm{~min}$, apart from day 8 , and is likely a contributory factor to the stable performance over the 10 days. 


\subsection{Other Parameters}

Blood glucose decreased from $6.1 \mathrm{mmol} . \mathrm{L}^{-1}$ pre run to $5.4 \mathrm{mmol} . \mathrm{L}^{-1}$ post-run; somewhat surprisingly SG was not hypoglycaemic following completion of each marathon despite very low calorie and $\mathrm{CHO}$ intake during each run $(67.7 \pm 51.5 \mathrm{kcal})$. A more notable decrease would be expected when running for more than $4 \mathrm{~h}$ but suggests a sparing of glycogen utilisation in favour of fat oxidation in our athlete [55], and/or maintenance via gluconeogenic pathways.

We observed a $2 \%$ decrease in Hct (from 39\% to 37\%) from the first to the tenth day, but no change in $\mathrm{Hb}$, in contrast to previous findings by Knechtle et al. [47], who found a $1.5 \pm 3.5 \%$ change in Hct after a $100 \mathrm{~km}$ race. This suggests an absence of plasma volume expansion, which is the usual cause for decreases in $\mathrm{Hb}$ in long endurance events [15].

For all 10 marathons combined the heart rate was the same for the 1st and 2nd hour of each marathon and then increased for the 3rd and 4th hour for each marathon and averaged $137 \pm 6 \mathrm{~b} \cdot \mathrm{min}^{-1}$ 1st hour, $137 \pm 5 \mathrm{~b} \cdot \mathrm{min}^{-1}$ 2nd hour, $145 \pm 6 \mathrm{~b} \cdot \mathrm{min}^{-1} 3 \mathrm{rd}$ hour, and $151 \pm 5 \mathrm{~b} \cdot \mathrm{min}^{-1} 4$ th hours. This increase in HR indicates a slight increase in the cost of running and fatigue as there was no increase in pace from beginning to end [56]. The cost of running is measured either as the oxygen required (in $\mathrm{mL} \cdot \mathrm{kg}^{-1} \cdot \mathrm{min}^{-1}$ ) or the energy required $\left(\mathrm{J} \cdot \mathrm{kg}^{-1} \cdot \mathrm{min}^{-1}\right)$ and is fundamental to performance in long-distance running [57-59] because it shows the relative amount of sustainable capacity that is utilised at any given moment. For low work rates (e.g., below the first lactate turn point, LT1), the cost of exercise is relatively constant. At higher work rates, there is an additional and delayed cost that increases the energetic demands of locomotion [60-62].

Despite this clearly strenuous task, feedback from SG on the difficulty of the event was that she did not complain of real tiredness, but that the fatigue was akin to that she experienced in regular training. She expressed that her legs ached but felt that she recovered before each new marathon. This statement is similar to her experience during the previous world record where she set the record for running consecutively for 7 days [33]. SG stated that she did not find running a marathon every day for 10 days that challenging but suffered with boredom due to the monotony of the task, especially during the final $2 \mathrm{~h}$ of each marathon. It is well documented that pain tolerance is higher in ultra-runners [63], and as an experienced ultra-marathon runner SG is used to prolonged bouts of pain and discomfort, but strategies to alleviate boredom may have enhanced her performance further.

\subsection{Strengths and Limitations}

We were fortunate that SG's record attempt took place in the same building as the Sports Science labs of Teesside University which allowed easy access to our equipment and simplified data collection. Many record attempts take place in remote locations, thus reducing data collection opportunities. This proximity led to the very detailed analysis of performance and changes in physiology that have rarely been reported in this detail for a live event where a world record of such long duration was broken.

Limitations to our work include estimations of EE throughout the day and using BIA for changes in body composition. BMR was calculated via BIA but did not include any EE measures for periods between the marathons, leading to a possible underestimation of total EE for the day. However, SG minimised her activity between attempts and only travelled to and from the venue (a short $15 \mathrm{~min}$ car journey). She rested for the remainder of the day and had her meals prepared for her. As such we are confident that total EE is not significantly different to that reported. We acknowledge that the use of BIA within athletic populations may be less reliable than in clinical populations when assessing change at the population level $[64,65]$, however from a practical standpoint, given the high ICC of the reported device to dual-energy X-ray absorptiometry [42,43] we are satisfied that some degree of change that is meaningful to the athlete occurred. 


\section{Conclusions}

We conclude that the successful record attempt was the result of a very stable pacing strategy, which was rigorously adhered to across all 10 marathons, carefully planned recovery strategies, and minimal physiological perturbations. The negligible fluctuation in the completion times highlight that SG was aware of her capabilities and confidently carried out her pre-determined race-pace, with only small variations in pace to alleviate monotony. SG favoured pre-race-, recovery-, and evening meals over in-race nutrition (due to nausea). Her excellent exercise economy and enhanced ability to metabolise fat as a fuel have previously been documented by us across seven days [33]. Although this clearly works for SG, it is not a strategy we would recommend to other athletes, as this would most likely lead to a performance drop after approximately three hours. Recommendations for similar events are, therefore, to plan and rigorously follow a realistic pace, ensure recovery strategies are in place immediately post-run, and allow sufficient periods for good quality sleep of long durations.

Author Contributions: Conceptualization, N.B.; methodology, N.B., D.C., M.G., C.H. and G.C.; formal analysis, N.B. and R.B.; writing—original draft preparation, N.B. and R.B.; writing—review and editing, N.B. and R.B.; supervision, N.B., D.C. and G.C. All authors have read and agreed to the published version of the manuscript.

Funding: This research received no external funding.

Institutional Review Board Statement: The study was conducted according to the guidelines of the Declaration of Helsinki and approved by the Institutional Review Board (or Ethics Committee) of Teesside University (November 2017).

Informed Consent Statement: Informed consent was obtained from all subjects involved in the study. Written informed consent has been obtained from the patient(s) to publish this paper.

Data Availability Statement: The data presented in this study are available on request from the corresponding author. The data are not publicly available due to the data in the present study pertaining to only one athlete.

Acknowledgments: We would like to thank the technical staff and volunteers for their continued support and thorough work.

Conflicts of Interest: The authors declare no conflict of interest.

\section{References}

1. Christensen, D.L.; Nielsen, T.H.; Schwartz, A. Herodotos and Hemerodromoi: Pheidippides' Run from Athens to Sparta in 490 BC from Historical and Physiological Perspectives. Hermes 2009, 137, 148-169.

2. Matthews, V.J. The "Hemerodromoi": Ultra Long-Distance Running in Antiquity. Class World 1974, 68, 161. [CrossRef]

3. Knechtle, B.; Nikolaidis, P.T. Physiology and Pathophysiology in Ultra-Marathon Running. Front. Physiol. 2018, 9, 8-33. [CrossRef] [PubMed]

4. Knechtle, B.; Kohler, G. Running 338 Kilometres within Five Days has no Effect on Body Mass and Body Fat but Reduces Skeletal Muscle Mass-the Isarrun 2006. J. Sports Sci. Med. 2007, 6, 401-407.

5. Bircher, S.; Enggist, A.; Jehle, T.; Knechtle, B. Effects of an extreme endurance race on energy balance and body composition-A case study. J. Sports Sci. Med. 2006, 5, 154-162. [PubMed]

6. Machefer, G.; Groussard, C.; Zouhal, H.; Vincent, S.; Youssef, H.; Faure, H.; Malardé, L.; Gratas-Delamarche, A. Nutritional and Plasmatic Antioxidant Vitamins Status of Ultra Endurance Athletes. J. Am. Coll. Nutr. 2007, 26, 311-316. [CrossRef]

7. Enqvist, J.K.; Mattsson, C.M.; Johansson, P.H.; Brink-Elfegoun, T.; Bakkman, L.; Ekblom, B.T. Energy turnover during 24 h and 6 days of adventure racing. J. Sports Sci. 2010, 28, 947-955. [CrossRef]

8. Hoogervorst, D.; van der Burg, N.; Versteegen, J.J.; Lambrechtse, K.J.; Redegeld, M.I.; Cornelissen, L.A.J.; Wardenaar, F.C. Gastrointestinal Complaints and Correlations with Self-Reported Macronutrient Intake in Independent Groups of (Ultra)Marathon Runners Competing at Different Distances. Sports 2019, 7, 140. [CrossRef]

9. Knechtle, B.; Knechtle, P.; Rosemann, T.; Senn, O. What is associated with race performance in male 100-km ultra-marathonersanthropometry, training or marathon best time? J. Sports Sci. 2011, 29, 571-577. [CrossRef]

10. Schütz, U.H.; Billich, C.; König, K.; Würslin, C.; Wiedelbach, H.; Brambs, H.-J.; Machann, J. Characteristics, changes and influence of body composition during a $4486 \mathrm{~km}$ transcontinental ultramarathon: Results from the Transeurope Footrace mobile whole body MRI-project. BMC Med. 2013, 11, 122. [CrossRef] 
11. Baur, D.A.; Bach, C.W.; Hyder, W.J.; Ormsbee, M.J. Fluid retention, muscle damage, and altered body composition at the Ultraman triathlon. Eur. J. Appl. Physiol. 2016, 116, 447-458. [CrossRef]

12. Smith, K.A.; Kisiolek, J.N.; Willingham, B.D.; Morrissey, M.C.; Leyh, S.M.; Saracino, P.G.; Baur, D.A.; Cook, M.D.; Ormsbee, M.J. Ultra-endurance triathlon performance and markers of whole-body and gut-specific inflammation. Eur. J. Appl. Physiol. 2020, 120, 349-357. [CrossRef] [PubMed]

13. Chiu, Y.-H.; Lai, J.-I.; Wang, S.-H.; How, C.-K.; Li, L.-H.; Kao, W.-F.; Yang, C.-C.; Chen, R.-J. Early changes of the anemia phenomenon in male 100-km ultramarathoners. J. Chin. Med. Assoc. 2015, 78, 108-113. [CrossRef] [PubMed]

14. Cejka, C.; Knechtle, B.; Knechtle, P.; Rüst, C.A.; Rosemann, T. An increased fluid intake leads to feet swelling in 100-km ultra-marathoners-an observational field study. J. Int. Soc. Sport Nutr. 2012, 9, 11. [CrossRef]

15. Liu, C.-H.; Tseng, Y.-F.; Lai, J.-I.; Chen, Y.-Q.; Wang, S.-H.; Kao, W.-F.; Li, L.-H.; Chiu, Y.-H.; How, C.-K.; Chang, W.-H. The changes of red blood cell viscoelasticity and sports anemia in male 24-h ultra-marathoners. J. Chin. Med. Assoc. 2018, 81, 475-481. [CrossRef]

16. Bossi, A.H.; Matta, G.G.; Millet, G.Y.; Lima, P.; Pertence, L.C.; de Lima, J.P.; Hopker, J.G. Pacing Strategy During 24-h Ultramarathon-Distance Running. Int. J. Sports Physiol. Perform. 2017, 12, 590-596. [CrossRef] [PubMed]

17. Hoffman, M.D.; Valentino, T.R.; Stuempfle, K.J.; Hassid, B.V. A Placebo-Controlled Trial of Riboflavin for Enhancement of Ultramarathon Recovery. Sports Med.-Open 2017, 3, 14. [CrossRef]

18. Kerksick, C.M.; Wilborn, C.D.; Roberts, M.D.; Smith-Ryan, A.; Kleiner, S.M.; Jäger, R.; Collins, R.; Cooke, M.; Davis, J.N.; Galvan, E.; et al. ISSN exercise \& sports nutrition review update: Research \& recommendations. J. Int. Soc. Sport Nutr. 2018, 15, 38. [CrossRef]

19. Jayanama, K.; Putadechakun, S.; Srisuwarn, P.; Vallibhakara, S.A.-O.; Shantavasinkul, P.C.; Sritara, C.; Kantachuvesiri, S.; Komindr, S. Evaluation of Body Composition in Hemodialysis Thai Patients: Comparison between Two Models of Bioelectrical Impedance Analyzer and Dual-Energy X-Ray Absorptiometry. J. Nutr. Metab. 2018, 2018, 4537623. [CrossRef]

20. Winter, E.M.; Jones, A.M.; Davison, R.C.R.; Bromley, P.D.; Mercer, T.H. Sport and Exercise Physiology Testing Guidelines: The British Association of Sport and Exercise Sciences Guide; Taylor \& Francis: Abingdon-on-Thames, UK, 2016.

21. Frayn, K.N. Calculation of substrate oxidation rates in vivo from gaseous exchange. J. Appl. Physiol. Respir. Environ. Exerc. Physiol. 1983, 55, 628-634. [CrossRef]

22. Borg, G. Borg's Perceived Exertion and Pain Scales; Human Kinetics: Champaign, IL, USA, 1998; ISBN 9780880116237.

23. Burke, L.M.; Hawley, J.A.; Wong, S.H.S.; Jeukendrup, A.E. Carbohydrates for training and competition. J. Sport Sci. 2011, 29, S17-S27. [CrossRef]

24. Thomas, D.T.; Erdman, K.A.; Burke, L.M. American College of Sports Medicine Joint Position Statement. Nutrition and Athletic Performance. Med. Sci. Sports Exerc. 2016, 48, 543-568. [CrossRef]

25. Venkatraman, J.T.; Leddy, J.; Pendergast, D. Dietary fats and immune status in athletes: Clinical implications. Med. Sci. Sports Exerc. 2000, 32, S389-S395. [CrossRef] [PubMed]

26. Jeukendrup, A. A Step Towards Personalized Sports Nutrition: Carbohydrate Intake During Exercise. Sports Med. 2014, 44, 25-33. [CrossRef]

27. Close, G.L.; Hamilton, D.L.; Philp, A.; Burke, L.M.; Morton, J.P. New strategies in sport nutrition to increase exercise performance. Free. Radic. Biol. Med. 2016, 98, 144-158. [CrossRef] [PubMed]

28. Richard, N.A.; Koehle, M.S. Optimizing recovery to support multi-evening cycling competition performance. Eur. J. Sport Sci. 2018, 19, 811-823. [CrossRef]

29. Viribay, A.; Arribalzaga, S.; Mielgo-Ayuso, J.; Castañeda-Babarro, A.; Seco-Calvo, J.; Urdampilleta, A. Effects of 120 g/h of Carbohydrates Intake during a Mountain Marathon on Exercise-Induced Muscle Damage in Elite Runners. Nutrients 2020, 12, 1367. [CrossRef]

30. Tiller, N.B.; Roberts, J.D.; Beasley, L.; Chapman, S.; Pinto, J.M.; Smith, L.; Wiffin, M.; Russell, M.; Sparks, S.A.; Duckworth, L.; et al International Society of Sports Nutrition Position Stand: Nutritional considerations for single-stage ultra-marathon training and racing. J. Int. Soc. Sports Nutr. 2019, 16, 50. [CrossRef]

31. Best, R.; Barwick, B.; Best, A.; Berger, N.; Harrison, C.; Wright, M.; Sparrow, J. Changes in Pain and Nutritional Intake Modulate Ultra-Running Performance: A Case Report. Sports 2018, 6, 111. [CrossRef]

32. Muros, J.J.; Sanchex-Munoz, C.; Hoyos, J.; Zabala, M. Nutritional intake and body composition changes in a UCI World Tour cycling team during the Tour of Spain. Eur. J. Sport Sci. 2018, 19, 86-94. [CrossRef] [PubMed]

33. Berger, N.; Cooley, D.; Graham, M.; Harrison, C.; Best, R. Physiological Responses and Nutritional Intake during a 7-Day Treadmill Running World Record. Int. J. Environ. Res. Public Health 2020, 17, 5962. [CrossRef] [PubMed]

34. Wardenaar, F.C.; Dijkhuizen, R.; Ceelen, I.J.M.; Jonk, E.; Vries, J.H.M.D.; Witkamp, R.F.; Mensink, M. Nutrient Intake by Ultramarathon Runners: Can They Meet Recommendations? Int. J. Sport Nutr. Exerc. 2015, 25, 375-386. [CrossRef] [PubMed]

35. Bandegan, A.; Courtney-Martin, G.; Rafii, M.; Pencharz, P.B.; Lemon, P.W. Indicator Amino Acid-Derived Estimate of Dietary Protein Requirement for Male Bodybuilders on a Nontraining Day Is Several-Fold Greater than the Current Recommended Dietary Allowance. J. Nutr. 2017, 147, 850-857. [CrossRef]

36. Schoenfeld, B.J.; Aragon, A.A. How much protein can the body use in a single meal for muscle-building? Implications for daily protein distribution. J. Int. Soc. Sport Nutr. 2018, 15, 10. [CrossRef]

37. Yang, Y.; Churchward-Venne, T.A.; Burd, N.A.; Breen, L.; Tarnopolsky, M.A.; Phillips, S.M. Myofibrillar protein synthesis following ingestion of soy protein isolate at rest and after resistance exercise in elderly men. Nutr. Metab. 2012, 9, 57. [CrossRef] 
38. Wall, B.T.; Gorissen, S.H.; Pennings, B.; Koopman, R.; Groen, B.B.L.; Verdijk, L.B.; van Loon, L.J.C. Aging Is Accompanied by a Blunted Muscle Protein Synthetic Response to Protein Ingestion. PLoS ONE 2015, 10, e0140903. [CrossRef]

39. Moore, D.R.; Churchward-Venne, T.A.; Witard, O.; Breen, L.; Burd, N.A.; Tipton, K.D.; Phillips, S.M. Protein Ingestion to Stimulate Myofibrillar Protein Synthesis Requires Greater Relative Protein Intakes in Healthy Older Versus Younger Men. J. Gerontol. Ser. Biol. Sci. Med. Sci. 2014, 70, 57-62. [CrossRef] [PubMed]

40. Rennie, M.J.; Edwards, R.H.T.; Davies, C.T.M.; Krywawych, S.; Halliday, D.; Waterlow, J.C.; Millward, D.J. Protein and amino acid turnover during and after exercise. Biochem. Soc. Trans. 1980, 8, 499-501. [CrossRef] [PubMed]

41. Evans, W.J.; Fisher, E.C.; Hoerr, R.A.; Young, V.R. Protein Metabolism and Endurance Exercise. Physician Sportsmed. 1983, 11, 63-162. [CrossRef]

42. Suida, A.R. Validity of Whole and Regional Body Composition Testing Devices; Northern Illinois University: DeKalb, IL, USA, 2016.

43. Buckinx, F.; Reginster, J.-Y.; Dardenne, N.; Croisiser, J.-L.; Kaux, J.-F.; Beaudart, C.; Slomian, J.; Bruyère, O. Concordance between muscle mass assessed by bioelectrical impedance analysis and by dual energy X-ray absorptiometry: A cross-sectional study. BMC Musculoskelet Disord. 2015, 16, 60. [CrossRef] [PubMed]

44. Venables, M.C.; Achten, J.; Jeukendrup, A.E. Determinants of fat oxidation during exercise in healthy men and women: A cross-sectional study. J. Appl. Physiol. 2005, 98, 160-167. [CrossRef]

45. Gibala, M.J. Protein Metabolism and Endurance Exercise. Sports Med. 2007, 37, 337-340. [CrossRef]

46. Gualano, A.B.; Bozza, T.; Lopes, D. Branched-chain amino acids supplementation enhances exercise capacity and lipid oxidation during endurance exercise after muscle glycogen depletion. J. Sports Med. Phys. Fit. 2011, 51, 82-88.

47. Knechtle, B.; Senn, O.; Imoberdorf, R.; Joleska, I.; Wirth, A.; Knechtle, P.; Rosemann, T. Maintained Total Body Water Content and Serum Sodium Concentrations Despite Body Mass Loss in Female Ultrarunners Drinking Ad Libitum during a $100 \mathrm{Km}$ Race. Asia Pac. J. Clin. Nutr. 2010, 19, 83. [PubMed]

48. Beis, L.Y.; Wright-Whyte, M.; Fudge, B.; Noakes, T.; Pitsiladis, Y.P. Drinking Behaviors of Elite Male Runners during Marathon Competition. Clin. J. Sport Med. 2012, 22, 254-261. [CrossRef]

49. Kipps, C.; Sharma, S.; Pedoe, D.T. The incidence of exercise-associated hyponatraemia in the London marathon. Brit. J. Sport Med. 2011, 45, 14. [CrossRef] [PubMed]

50. Hoffman, M.D.; Krishnan, E. Health and Exercise-Related Medical Issues among 1212 Ultramarathon Runners: Baseline Findings from the Ultrarunners Longitudinal TRAcking (ULTRA) Study. PLoS ONE 2014, 9, e83867. [CrossRef]

51. Goedecke, J.H.; Gibson, A.S.C.; Grobler, L.; Collins, M.; Noakes, T.D.; Lambert, E.V. Determinants of the variability in respiratory exchange ratio at rest and during exercise in trained athletes. Am. J. Physiol.-Endocrinol. Metab. 2000, 279, E1325-E1334. [CrossRef] [PubMed]

52. Brooks, G.A.; Mercier, J. Balance of carbohydrate and lipid utilization during exercise: The "crossover" concept. J. Appl. Physiol. 1994, 76, 2253-2261. [CrossRef] [PubMed]

53. Helge, J.; Fraser, A.; Kriketos, A.; Jenkins, A.; Calvert, G.; Ayre, K.; Storlien, L. Interrelationships between muscle fibre type, substrate oxidation and body fat. Int. J. Obes. 1999, 23, 986-991. [CrossRef] [PubMed]

54. Knufinke, M.; Nieuwenhuys, A.; Geurts, S.A.E.; Møst, E.I.S.; Maase, K.; Moen, M.H.; Coenen, A.M.L.; Kompier, M.A.J. Train hard, sleep well? Perceived training load, sleep quantity and sleep stage distribution in elite level athletes. J. Sci. Med. Sport 2018, 21, 427-432. [CrossRef] [PubMed]

55. Urdampilleta, A.; Arribalzaga, S.; Viribay, A.; Castañeda-Babarro, A.; Seco-Calvo, J.; Mielgo-Ayuso, J. Effects of 120 vs. 60 and $90 \mathrm{~g} / \mathrm{h}$ Carbohydrate Intake during a Trail Marathon on Neuromuscular Function and High Intensity Run Capacity Recovery. Nutrients 2020, 12, 2094. [CrossRef] [PubMed]

56. Brueckner, J.C.; Atchou, G.; Capelli, C.; Duvallet, A.; Barrault, D.; Jousselin, E.; Rieu, M.; Prampero, P.E.d. The energy cost of running increases with the distance covered. Eur. J. Appl. Physiol. 1991, 62, 385-389. [CrossRef]

57. Daniels, J.; Daniels, N. Running economy of elite male and elite female runners. Med. Sci. Sports Exerc. 1992, $24,483-489$. [CrossRef] [PubMed]

58. Joyner, M.J. Modeling: Optimal marathon performance on the basis of physiological factors. J. Appl. Physiol. 1991, 70, 683-687. [CrossRef] [PubMed]

59. Foster, C.; Lucia, A. Running economy: The forgotten factor in elite performance. Sports Med. 2007, 37, 316-319. [CrossRef]

60. Barstow, T.J.; Mole, P.A. Linear and nonlinear characteristics of oxygen uptake kinetics during heavy exercise. J. Appl. Physiol. 1991, 71, 2099-2106. [CrossRef]

61. Paterson, D.H.; Whipp, B.J. Asymmetries of oxygen uptake transients at the on- and offset of heavy exercise in humans. J. Physiol. 1991, 443, 575-586. [CrossRef]

62. Bearden, S.E.; Moffatt, R.J. VO(2) kinetics and the $\mathrm{O}_{2}$ deficit in heavy exercise. J. Appl. Physiol. 2000, 88, 1407-1412. [CrossRef]

63. Roebuck, G.S.; Fitzgerald, P.B.; Urquhart, D.M.; Ng, S.-K.; Cicuttini, F.M.; Fitzgibbon, B.M. The psychology of ultra-marathon runners: A systematic review. Psychol. Sport Exerc. 2018, 37, 43-58. [CrossRef]

64. Buffa, R.; Mereu, E.; Comandini, O.; Ibanez, M.E.; Marini, E. Bioelectrical impedance vector analysis (BIVA) for the assessment of two-compartment body composition. Eur. J. Clin. Nutr. 2014, 68, 1234-1240. [CrossRef] [PubMed]

65. Castizo-Olier, J.; Irurtia, A.; Jemni, M.; Carrasco-Marginet, M.; Fernandez-Garcia, R.; Rodriguez, F.A. Bioelectrical impedance vector analysis (BIVA) in sport and exercise: Systematic review and future perspectives. PLoS ONE 2018, 13, e0197957. [CrossRef] [PubMed] 